\title{
PIE JAMBU KRISTAL UPAYA DIVERSIFIKASI PRODUK PETANI JAMBU DI BUMIAJI KOTA BATU
}

\author{
${ }^{1}$ Imama Zuchroh ${ }^{2}$ Setiawan ${ }^{3}$ Siwi Dyah Ratnasari ${ }^{4}$ Yupono Bagyo \\ Program Studi Manajemen, STIE Malangkuçeçwara Malang
}

\begin{abstract}
Abstrak
Mitra dalam Program Kemitraan Masyarakat (PKM) ini adalah Petani Jambu kristal di Desa Bumiaji. Desa Bumiaji, Kota Batu, Jawa Timur. Merupakan Desa yang memiliki potensi besar sebagai agro wisata. Sebagai Agro Wisata, UMKM di Desa Bumiaji berupaya menjadikan wisata petik jambu sebagai edu wisata selain pemasaran melalui supermarket dan online. Hasil jambu yang dipanen oleh petani jambu tidak semuanya bisa diterima oleh pasar terutama Supermarket yang memiliki standar-standar kualitas tertentu. Jambu Kristal yang direject oleh supermarket menjadi masalah tersendiri bagi petani jambu karena jambu yang sudah dipanen akan berakibat layu dan busuk.

Metode pelaksanaan Program Kemitraan Masyarakat ini dilakukan melalui pelatihan, magang UKM ke SMK Batu serta pendampingan. Pelatihan dan pendampingan terhadap UKM prioritas di bidang keuangan, pemasaran dan produksi.

Luaran yang dihasilkan dari PKM ini adalah adanya diversifikasi produk jambu kristal menjadi pie jambu kristal. Peningkatan kemampuan mitra di bidang produksi dan keuangan telah menyebabkan peningkatan pendapatan bagi mitra serta mengurangi resiko kerugian akibat jambu busuk.
\end{abstract}

Keyword: Jambu Kristal, Kue Pai, Bumiaji

\section{PENDAHULUAN}

Mitra Program Kemitraan Masyarakat (PKM) ini yaitu petani jambu kristal di Desa Bumiaji Batu, Jawa Timur. Luas lahan tanaman jambu kristal sekitar 4000 meter menjadi idola pengunjung petik buah di Kota Batu. Tanaman jambu Kristal buahnya terus menerus tanpa mengenal musim jika pemeliharaan terhadap kebutuhan tanaman dilakukan secara optimal. Hasil panen jambu perminggu mencapai 1 ton yang meliputi grade A dan grade B. Berikut adalah Kecamatan Bumiaji Kota Batu. 

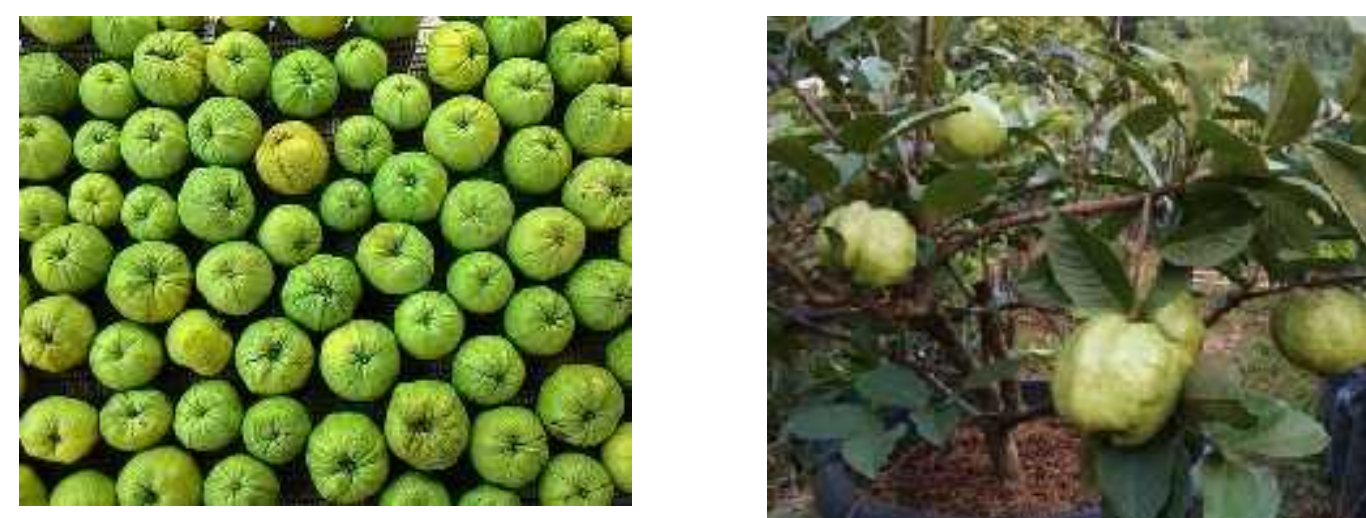

Gambar 1. Jambu Kristal yang dihasilkan oleh Petani-petani jambu kristal di Desa Bumiaji Kota Batu

Hasil jambu yang dipanen oleh petani jambu kristal berkisar untuk grade A Rp 15.000,untuk grade A dan Rp 13.000,- untuk grade B.

Kendala yang dihadapi oleh petani jambu kristal adalah bahwa jambu kristal yang dihasilkan tidak semuanya bisa diterima oleh supermarket/pasar karena cacat burik dan sebagainya. Hampir 30\% jambu-jambu Kristal yang dipanen oleh petani saat dikirim ke supermarket direject karena tidak memenuhi standart. Jambu-jambu yang direject ini kalau dibiarkan dan tidak ada pembeli lain berakibat menjadi jambu busuk dan merupakan kerugian bagi petani jambu kristal. Atas dasar inilah petani jambu kristal ingin membuat diversifikasi produk yaitu mengolah jambu Kristal menjadi kue Pie. Alasan Petani melakukan diversifikasi dengan membuat kue pie dari jambu Kristal adalah:

1. Hampir 30\% jambu-jambu Kristal yang dipanen oleh petani direject oleh supermarket karena kurang memenuhi standar (cacat burik)

2. Menghindari kebusukan jambu Kristal yang sudah dipanen

3. Memberikan nilai tambah produk

4. Masih sangat sedikit pesaingnya. Olahan kue pie dari jambu Kristal masih belum ada, sementara yang ada adalah pie dari apel atau yg lebih dikenal dengan strudel

5. Rasa jambu Kristal renyah seperti apel sehingga cocok jika diolah menjadi kue pie

6. Kue pie hasil olahan buah dengan rasa buah segar saat ini menjadi kegemaran masyarakat dan sangat cocok buat oleh-oleh dan masih sangat jarang pesaingnya tidak seperti produk minuman dari buah.

7. Konsep pembuatan kue pie dilakukan melakukan edukasi raw to table yaitu pembeli langsung memasak jambu Kristal menjadi kue pie akan memberikan daya tarik tersendiri kepada konsumen. Pembeli yang datang ke kebun dapat memetik jambu Kristal secara langsung dan edukasi memasak kue pai dalam jangka waktu maksimum 20 menit.

8. Keinginan yang kuat dari Petani pioner untuk mengembangkan usahanya dengan melakukan diversifikasi produk yaitu membuat olahan jambu Kristal menjadi kue pie.

Dicanangkannya Desa Bumiaji sebagai Desa Wisata oleh Bapak Walikota Kota Batu, Petani berusaha mengembangkan tanaman jambu kristal tidak hanya untuk dijual secara langsung atau online tetapi berusaha mengembangkan tanaman jambu Kristal ini sebagai 
eduwisata. Sebagai eduwisata petani juga memiliki pemikiran untuk melakukan diversifikasi produk jambu Kristal melalui pembuatan pie jambu Kristal dengan konsep Raw to table yaitu pembeli setelah memetik jambu Kristal dapat memasak sendiri dengan waktu maksimum 20 menit. Keinginan untuk melakukan diversifikasi produk didasari pada kenyataan bahwa hampir $30 \%$ jambu Kristal yang dihasilkan dan dikirim ke supermarket di reject karena produk tidak sesuai kualitas karena tampilan buah burik dan sebagainya. Akibatnya jika dibiarkan begitu saja jambu akan layu dan busuk. Pengolahan jambu-jambu Kristal yang di reject ini akan meningkatkan nilai tambah produk serta mencegah resiko kerugian karena buah busuk. Rasa jambu Kristal yang renyah seperti apel sangat cocok sebagai bahan kue pie, dimana pesaingnya juga masih sedikit, itupun pie yang berbahan apel.

Berikut adalah proses kegiatan yang dilakukan dalam Program PKM Pie Jambu Cristal dpat dilihat pada gambar 2 di bawah ini:

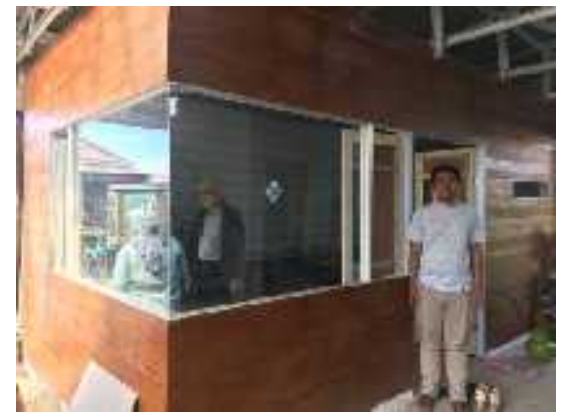

Penyertaan rumah produksi oleh mitra dan pelatihan bidang keuangan

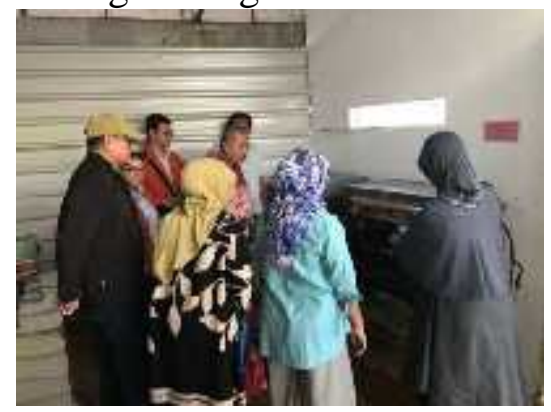

Pendampingan di bidang produksi

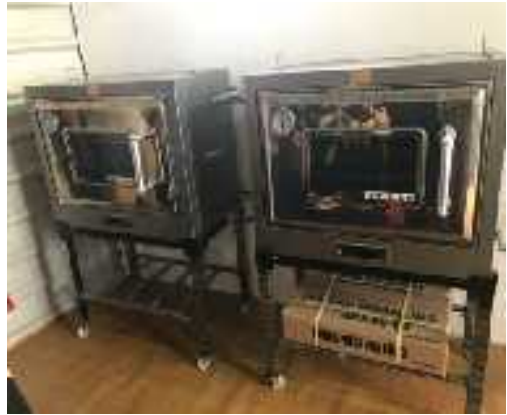

Salah satu Peralatan produksi untuk mengolah pie jambu kristal

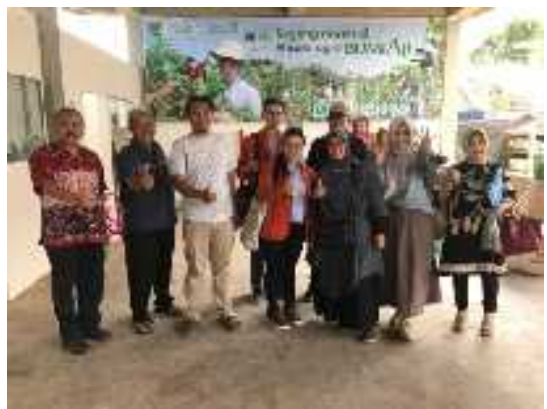

Foto bersama setelah pendampingan

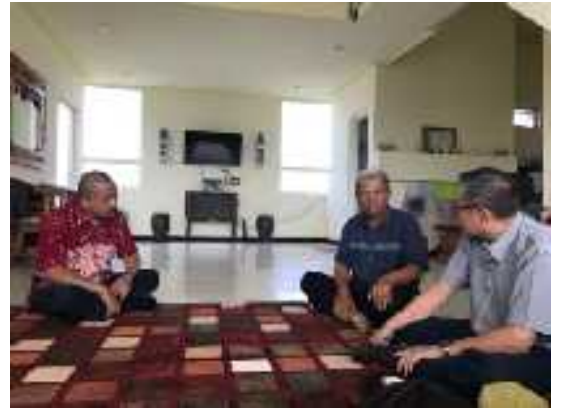

Pendampingan di bidang pemasaran

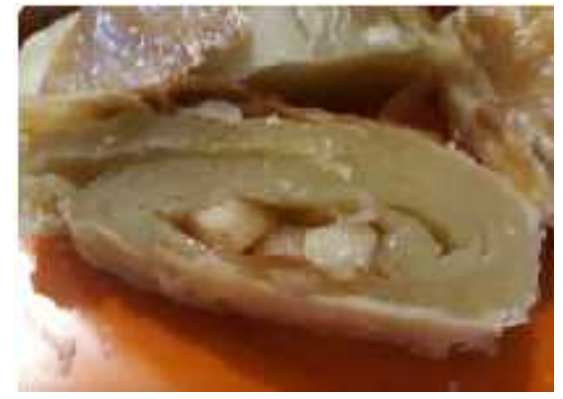

Hasil diversifikasi produk: Pie jambu kristal

\section{Gambar 2: Proses Kegiatan PKM}

Berdasarkan analisis situasi dan wawancara dengan Mitra, ada 3 masalah yang berkaitan dalam pengembangan usaha, yaitu:

1. Permasalahan dari aspek Sumber Daya Manusia (SDM)

Belum adanya kemampuan dan ketrampilan Mitra dalam menciptakan keinginan melakukan diversifikasi produk yaitu mengolah jambu Kristal menjadi kue pie

2. Permasalahan dari aspek Keuangan

Catatan laporan keuangan tang dilakukan oleh mitra belum sesuai PSAK

3. Permasalahan dari Aspek produksi: 
Permasalahan dibidang produksi dapat diidentifikasikan sebagai berikut: Mitra belum memiliki peralatan untuk mengolah jambu kristal menjadi pie jambu kristal

Berdasarkan analisis situasi diatas dan hasil wawancara dengan kedua mitra maka dapat dirumuskan permasalahan-permasalahan yang perlu mendapatkan solusi penyelesaiannya seperti dalam tabel 2 berikut:

Tabel 1 Permasalahan dan Target Luaran

\begin{tabular}{|l|l|l|}
\hline \multicolumn{2}{|l|}{ Permasalahan } & Target Luaran \\
\hline 1. Permasalahan dibidang SDM & $\begin{array}{l}\text { Belum adanya kemampuan dan ketrampilan Mitra } \\
\text { dalam menciptakan keinginannya untuk melakukan } \\
\text { diversifikasi produk yaitu mengolah jambu Kristal } \\
\text { menjadi kue pie }\end{array}$ & $\begin{array}{l}\text { Memberikan pelatihan } \\
\text { pengolahan jambu Kristal } \\
\text { menjadi aneka kue pie yang } \\
\text { bekerjasama dengan tim ahli }\end{array}$ \\
\hline 2. Permasalahan dalam bidang Keuangan: & $\begin{array}{l}\text { Pengetahuan mitra 1 mengenai manajemen keuangan } \\
\text { masih sangat terbatas. Mitra 1 (Petani plasma) } \\
\text { notabennya memiliki pendidikan }\end{array}$ & $\begin{array}{l}\text { Pelatihan tentang penyusunan } \\
\text { laporan keuangan sederhana } \\
\text { bagi Mitra 1 }\end{array}$ \\
\hline 3. Permasalahan dalam bidang produksi: & $\begin{array}{l}\text { Pidak semua produk jambu Kristal hasil panen petani } \\
\text { dapat diterima oleh pasar, terutama supermarket (ada } \\
\text { jambu Kristal yang di reject saat pengiriman karena } \\
\text { jambu burik/kualitas tidak sesuai standar) }\end{array}$ & $\begin{array}{l}\text { Memanfaatkan jambu kristal } \\
\text { yang di reject oleh supermarket } \\
\text { menjadi produk yang bernilai } \\
\text { ekonomis tinggi dan memiliki } \\
\text { daya tahan lebih lama berupa } \\
\text { pie jambu kristal }\end{array}$ \\
\hline $\begin{array}{l}\text { 2. Adanya keinginan yang kuat dari Mitra untuk } \\
\text { melakukan diversifikasi peoduk yang dihasilkan } \\
\text { dengan alasan mengolala jambu Kristal yang di reject } \\
\text { sehingga tidak berakibat layu atau kebusukan dengan } \\
\text { konsep raw to table }\end{array}$ & $\begin{array}{l}\text { 3. Belum memiliki peralatan untuk mengolah jambu } \\
\text { kristal menjadi pie berbahan dasar jambu kristal }\end{array}$ & $\begin{array}{l}\text { Pengadaan peralatan untuk } \\
\text { mengolah jambu Kristal } \\
\text { menjadi pie }\end{array}$ \\
\hline
\end{tabular}

Program Kemitraan Masyarakat (PKM) ini mampu menciptakan penguatan finansial bagi petani jambu krital dengan semakin meningkatnya pendapatan dari hasil edu wisata serta peningkatan ketrampilan dalam membuat diversifikasi produk kue pie jambu kristal. Setelah kegiatan PKM, mitra mampu menciptakan lapangan pekerjaan bagi masyarakat sekitar.

\section{METODE}

Secara garis besar metode yang ditempuh dalam pelaksanaan Program Kemitraan Masyarakat (PKM) ini diringkas dalam tabel 2 berikut ini: 
Tabel 2 Metode Pelaksanaan Program Kemitraan Masyarakat (PKM)

\begin{tabular}{|l|l|}
\hline Permasalahan & \multicolumn{1}{c|}{ Metode } \\
\hline $\begin{array}{l}\text { 1. Permasalahan dibidang } \\
\text { keuangan }\end{array}$ & 1. Pelatihan penyusunan laporan keuangan sesuai PSAK \\
\cline { 2 - 2 } & $\begin{array}{l}\text { 2. Pendampingan penyusunan laporan keuangan sesuai } \\
\text { PSAK }\end{array}$ \\
\hline 2. Permasalahan di bidang SDM & \multicolumn{1}{c|}{ Pelatihan dan magang peningkatan kreatifitas SDM } \\
\hline $\begin{array}{l}\text { 3. Permasalahan dibidang } \\
\begin{array}{l}\text { produksi: Belum memiliki } \\
\text { keahlian dalam diversifikasi } \\
\text { jambu kristal menjadi Pie jambu } \\
\text { kristal }\end{array}\end{array}$ & $\begin{array}{l}\text { 1. Pelatihan pembuatan Pie jambu kristal } \\
\text { 3.Pendampingan proses pembuatan Pie jambu kristal }\end{array}$ \\
\hline
\end{tabular}

\section{HASIL DAN PEMBAHASAN}

Hasil dari kegiatan PKM dapat dilihat pada perbandingan hasil yang diperoleh sebelum dan sesudah kegiatan PKM yang disajikan dalam tabel 3 berikut:

Tabel 3 Perbandingan Hasil sebelum dan sesudah kegiatan Program Kemitraan Masyarakat (PKM)

\begin{tabular}{|l|l|l|}
\hline N0 & \multicolumn{1}{|c|}{ Sebelum Kegiatan PKM } & \multicolumn{1}{|c|}{ Sesudah Kegiatan PKM } \\
\hline 1 & $\begin{array}{l}\text { Belum ada pemanfaatan jambu Kristal } \\
\text { yang di reject (Jambu Burik) oleh } \\
\text { Supermarket }\end{array}$ & $\begin{array}{l}\text { Terpenuhinya harapan mitra untuk } \\
\text { mengolah jambu Kristal yang di reject } \\
\text { (Jambu Burik) oleh Supermarket menjadi } \\
\text { Pie Jambu Kristal }\end{array}$ \\
\hline 2 & $\begin{array}{l}\text { Belum adanya kemampuan dan } \\
\text { ketrampilan Mitra dalam menciptakan } \\
\text { diversifikasi produk yaitu mengolah } \\
\text { jambu Kristal menjadi kue pie } \\
\text { (Permasalahan dari aspek Sumber } \\
\text { Daya Manusia (SDM) }\end{array}$ & $\begin{array}{l}\text { Meningkatnya kemampuan dan ketrampilan } \\
\text { Mitra dalam menciptakan diversifikasi } \\
\text { produk yaitu mengolah jambu Kristal } \\
\text { menjadi kue pie }\end{array}$ \\
\hline 3 & $\begin{array}{l}\text { Belum memiliki peralatan untuk } \\
\text { mengolah jambu kristal menjadi pie } \\
\text { jambu Kristal (Permasalahan dari } \\
\text { Aspek produksi) }\end{array}$ & $\begin{array}{l}\text { Adanya Mesin Oven, meja produksi, Rumah } \\
\text { produksi, Blander, dll alat penunjang untuk } \\
\text { mengolah jambu Kristal yang di reject atau } \\
\text { Jambu Burik menjadi Pie Jambu Kristal }\end{array}$ \\
\hline 4 & $\begin{array}{l}\text { Belum memiliki catatan keuangan yang } \\
\text { benar (Permasalahan dari aspek } \\
\text { Keuangan) }\end{array}$ & $\begin{array}{l}\text { Meningkatnya kemampuan mitra dalam } \\
\text { menyusun Laporan Keuangan yang benar }\end{array}$ \\
\hline 5 & $\begin{array}{l}\text { Terbatasnya kerjasama dengan produsen } \\
\text { lain }\end{array}$ & $\begin{array}{l}\text { Meningkatnya kerjasama dibidang produksi } \\
\text { dan pemasaran }\end{array}$ \\
\hline
\end{tabular}

Dari tabel 3 dapat dilihat bahwa setelah kegiatan PKM terjadi peningkatan kemampuan mitra dibidang keuangan, peningkatan di bidang kerjasama dan pemasaran serta meningkatnya kemampuan dan ketrampilan mitra dalam menciptakan diversifikasi produk jambu kristal menjadi pie jambu kristal. 


\section{KESIMPULAN DAN SARAN}

\section{KESIMPULAN}

Program pendampingan yang telah dilakukan dalam program IbM menghasilkan kesimpulan sebagai berikut:

1. Peningkatan pengetahuan bagi Petani jambu kristal dalam memanfaatkan jambu yang di reject menjadi bernilai tinggi (pie jambu Kristal)

2. Kemampuan Petani jambu kristal dalam menghasilkan Pie sebagai aneka olahan jambu kristal

3. Peningkatan kreativitas dalam membuat makanan olahan jambu kristal

4. Peningkatan pendapatan

5. Menciptakan lapangan kerja bagi masyarakat sekitar

SARAN:

1. Masih diperlukan program pendampingan secara berkelanjutan guna peningkatan pengetahuan dan kreatifitas di bidang olahan jambu kristal

2. Sangat diperlukan dukungan dari semua pihak terutama pemerintah setempat guna lebih memperkenalkan dan memasarkan produk jambu kristal

\section{UCAPAN TERIMAKASIH}

Ucapan terimakasih diberikan kepada RISTEKDIKTI yang telah membiayai Program Kemitraan Masyarakat (PKM) tahun anggaran 2018

\section{REFERENSI}

Akaibara. 2017. Wisata Jambu Kristal yang Tak Kenal Musim. https://ngalam.co/2017/01/31/wisata-petik-jambu-kristal-tak-kenal-musim/

Malang Images.com. Wisata Petik Jambu Kristal Mulai Moncer di Kota Batu. http://www.malangtimes.com/baca/11729/20160409/131559/wisata-petik-jambu-kristalmulai-moncer-di-kota-batu/

Tabloid Sinar Tani. 2015. Olahan terkini Alternatif Pendapatan Keluarga. tabloid http://tabloidsinartani.com/content/read/olahan-terkini-alternatif-pendapatan-keluarga/ Rabu, 02 September 2015 | 